\title{
STRUKTUR KOMUNITAS MANGROVE ASOSIASI DI SEKITAR AREA TAMBAK DESA BALANDATU KEPULAUAN TANAKEKE \\ KABUPATEN TAKALAR SULAWESI SELATAN
}

\section{COMMUNITY STRUCTURE OF ASSOCIATED MANGROVE IN VICINITY OF FISHPOND BALANDATU VILLAGE, MAPPAKASUNGGU MUNICIPALITY, TAKALAR REGENCY, SOUTH SULAWESI}

\author{
Riska Annisa ${ }^{1}$, Dody Priosambodo ${ }^{1}$, Muhtadin Asnadi Salam ${ }^{1}$, Slamet Santosa ${ }^{1}$ \\ 1. Departemen Biologi, Fakultas Matematika dan Ilmu Pengetahuan Alam, Universitas \\ Hasanuddin, Makassar, 90245 \\ riska_annisa45@yahoo.co.id
}

\begin{abstract}
Abstrak
Penelitian tentang struktur komunitas mangrove asosiasi di sekitar area tambak telah dilakukan pada bulan Mei-Desember 2016 di Desa Balandatu Kecamatan Mappakasunggu Kabupaten Takalar Sulawesi Selatan. Penelitian ini bertujuan untuk mengetahui jenis, kerapatan, frekuensi, penutupan, INP, SDR (Standard Dominance Rasio), dan penyebaran mangrove asosiasi di daerah tersebut, serta membandingkan struktur komunitas mangrove asosiasi di daerah tambak dan non tambak. Pengambilan dilakukan dengan metode purposive sampling menggunakan transek sabuk di daerah tambak dan transek kuadrat di daerah non tambak. Data yang diperoleh dianalisis secara kuantitatif untuk mendapatkan nilai SDR (Standard Dominance Rasio). Data penyebaran spesies dihitung berdasarkan Indeks Morisita. Dari hasil pengambilan data diperoleh 36 spesies mangrove asosiasi dari 22 familia, terdiri dari 11 spesies ( 7 familia) di daerah tambak dan 26 spesies (19 familia) di daerah non tambak. Nilai SDR tertinggi dari 5 stasiun di daerah tambak terdapat di stasiun 1 ditemukan pada rumput Fimbristylis cymosa dengan nilai $100 \%$, sedangkan di daerah non tambak nilai SDR tertinggi ditemukan di stasiun 3 pada semak Kirinyu Eupatorium odoratum dengan nilai 75,48 \%. Mangrove asosiasi umumnya memiliki pola penyebaran mengelompok. Dapat disimpulkan bahwa mangrove assosiasi di daerah non tambak dan tambak memiliki struktur komunitas berbeda dengan penyebaran mengelompok.
\end{abstract}

Kata kunci: Struktur komunitas, mangrove asosiasi, Desa Balandatu, Tanakeke, Sulawesi Selatan

\section{Abstract}

Research about community structure of associated mangrove has been conducted on Mei-December 2016 in vicinity of fishpond Balandatu Village, Mappakasunggu Municipality, Takalar Regency, South Sulawesi. The aim of this research was to know species, density, frequency, coverage, INP, SDR (Standard Dominance Rasio), distribution of mangrove associated and compared community structure of associated mangrove from fishpond and outside fishpond. Data collected using purposive sampling method with belt transect in fishpond area and quadrate transect outside fishpond. Data were analysed quantitatively to determine SDR (Standard Dominance Rasio). Species distribution pattern were analysed using Morisita Dispertion Index. Result showed that 36 species of Associated mangrove from 22 familia was found in vicinity of fishpond. Eleven species ( 7 familia) recorded from fishpond and 26 species (19 familia) collected outside fishpond. The highest SDR from all stasions was found in grass species Fimbristylis cymosa in stasion 1 which value 100\%, while the highest SDR outside fishpond was found in Eupatorium odorata in stasion 3 which 75,48\%. Distribution pattern of associated mangrove tend to be clumped. It can be concluded that community structure of associated mangrove spesies in fishpond and outside fishpond were different with dispersion pattern to be clumped.

Keywords:Community Structure,Associated mangrove, Balandatu village, Tanakeke Islands, South Sulawesi. 


\section{Pendahuluan}

Mangrove merupakan vegetasi yang tumbuh di daerah pesisir berair asin atau payau dan dipengaruhi oleh pasang surut air laut dengan salinitas tanah yang tinggi.Mangrove menjadi bagian dari ekosistem pantai yang penting karena mampu melindungi pantai dari abrasi pantai dan dari arus pasang surut yang kuat,menangkap sedimen,menghasilkan oksigen, menyerap karbon dioksida, serta menjadi habitat bagi berbagai jenis biota laut. Berdasarkan habitatnya, mangrove dibedakan menjadi dua jenis, yaitu mangrove sejati (true mangrove) dan mangrove asosiasi (associate mangrove).Menurut Wang et. al (2010) mangrove sejati dan mangrove asosiasi memiliki perbedaan dari segi ekologis dan fisiologinya. Dari aspek ekologis mangrove sejati sepenuhnya hidup pada ekosistem pantai dengan dinamika pasang surut yang tinggi, fluktuasi salinitas besar, substrat labil (berlumpur) dengan kandungan oksigen rendah. Sedangkan mangrove asosiasi (associate mangrove)merupakan vegetasi yang tumbuh ke arah darat di belakang zona mangrove sejati, kurang dipengaruhi oleh pasang surut, dengan kondisi substrat (tanah) yang lebih stabil dan kering, fluktuasi salinitas yang rendah, dengan suhu yang tinggi serta tumbuh dominan pada suatu area tertentu dengan membentuk rumpun. Mangrove asosiasi umumnya terdiri dari berbagai jenis tumbuhan darat yang memiliki toleransi besar terhadap salinitas. Tumbuhan ini bersifat kosmopolit, seringkali juga ditemukan pada ekosistem lainnya seperti hutan dataran rendah.

Dari segi fisiologinya mangrove sejati memiliki batang yang lebih sukulen, osmolaritas yang lebih tinggi serta mengakumulasikan $\mathrm{Na}$ dan $\mathrm{Cl}$ 8-9 kali lebih banyak dari mangrove asosiasi. Sedangkan mangrove asosiasi memiliki luas SLA (Specific Leaf Area), konsentrasi nitrogen dan massa daun yang lebih tinggi dari mangrove sejati serta memiliki ratio $\mathrm{K} / \mathrm{Na}$ yang lebih tinggi. Mangrove sejati merupakan tumbuhan halophytes (toleran terhadap kadar garam tinggi) sedangkan mangrove asosiasi merupakan glycophytes (hanya dapat mentolerir konsentrasi garam dengan kadar tertentu) (Wang, et. al., 2010).

Menurut Noor et. al.(2006) Indonesia memiliki hutan mangrove dengan luas sekitar 3,5 juta hektar. Namun sebagian besar luasan mangrove tersebut telah beralih fungsi menjadi area tambak dan daerah permukiman.Kerusakan ekosistem mangrove juga terjadi akibat adanya eksploitasi hutan yang tidak terkendali oleh aktivitas manusia. Di Sulawesi Selatan, hutan mangrove sudah banyak yang berkurang, bahkan ketebalan formasinya hingga ke laut sudah sangat menipis. Dibandingkan dengan lokasi lain di Sulawesi Selatan kondisi mangrove di Kepulauan Tanakeke dikategorikan masih baik sebesar 16,46\% (Faizal, 2006). Sebagian besar area mangrove sejati dan mangrove asosisasi di Kepulauan Tanakeke telah dikonversi menjadi tambak dan ditebang untuk bahan baku pembuatan arang. Di Sulawesi Selatan, penelitian tentang mangrove sejati telah banyak dilakukan.Akan tetapi informasi terkait mangrove asosiasi baik komposisi jenis maupun struktur vegetasinya belum banyak diketahui.Berdasarkan hal tersebut maka dilakukan penelitian ini.

\section{Bahan dan Metode Penelitian}

\section{Alat dan Bahan}

Alat yang digunakan pada penelitian ini yaitu: Kompas, Global Positioning System (GPS), tali rafia, rol meter ukuran 50 meter, kertas label, kertas koran, parang, pisau, gunting, sasak herbarium, hand book (panduan pengenalan mangrove), kamera digital, 
drone (djipanthom 3) dan peta lokasi. Bahan yang digunakan adalah sampel tumbuhan mangrove asosiasi, alkohol $70 \%$ untuk pembuatan herbarium dan akuades.

\section{Metode Penelitian}

Metode penelitian yang digunakan adalah metode survei.Pengambilan data dilakukan dengan metode purposive sampling menggunakan transek kuadrat dan transek sabuk (belt).Data yang diperoleh dianalisis secara kuantitatif dengan menghitung kerapatan, frekuensi dan penutupan dari mangrove asosiasi yang tumbuh di lokasi penelitian.

\section{Deskripsi Lokasi Penelitian}

Lokasi penelitian terletak di Dusun Balandatu, Desa Balandatu, Kecamatan Mappakasunggu, Kepulauan Tanakeke, Kabupaten Takalar, Sulawesi Selatan. Di daerah ini banyak ditemukan area tambak dan vegetasi mangrove.Secara geomorfologi, Tanakeke berbentuk kepulauan yang terdiri dari beberapa pulau yang dihubungkan dengan hamparan hutan mangrove.Luas kepulauan Tanakeke sekitar $9 \mathrm{~km}^{2}$ dan terletak pada koordinat 5 $32^{\prime} 34^{\prime \prime}-5^{\circ} 26^{\prime} 43^{\prime \prime}$ LS dan $119^{\circ} 14^{\prime} 22^{\prime \prime}-119^{\circ} 20^{\prime} 29^{\prime \prime}$ BT (Brown, 2012).Bentuk Kepulauan Tanakeke tidak secara sporadis terpisah, tetapi cenderung dibatasi oleh perairan di dalam gugusan pulau dengan pola melingkar.Diperkirakan bahwa sangat mungkin areal ini dulunya adalah suatu pulau besar yang selanjutnya lewat peristiwa alamiah (abrasi, erosi, aksi fisik lautan, dan peristiwa alam lainnya) kemudian terbagi menjadi beberapa daratan pulau (Brown, 2012).

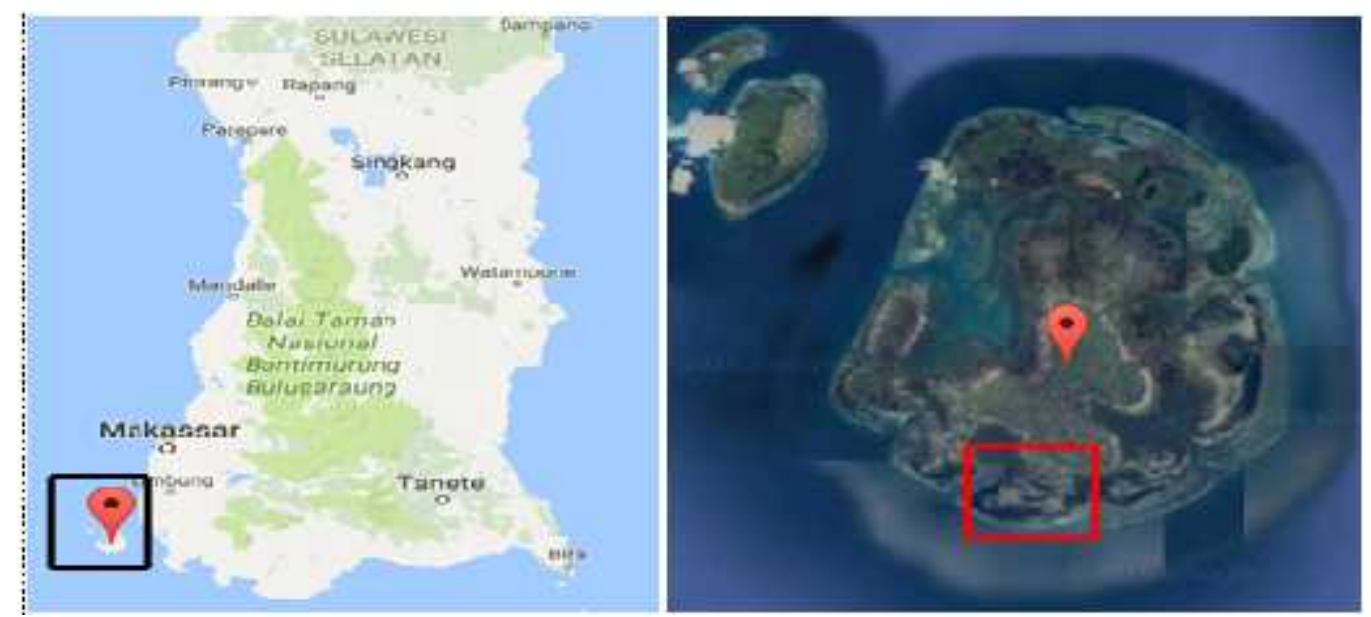

Gambar 1: Pulau Tanakeke, Kabupaten Takalar, Sulawesi Selatan

Sumber :Google earth (2016)

\section{Prosedur Kerja}

Pengambilan data dilakukan pada 10 stasiun, 5 stasiun di daerah tambak dan 5 stasiun di daerah non tambak. Pada setiap stasiun dibuat 1 transek dengan panjang yang berbeda di kedua lokasi pengambilan data yaitu 50 meter di daerah tambak dan 100 meter di daerah non tambak yang disesuaikan dengan lokasi. Berikut ini stasiun sampling mangrove asosiasi. 


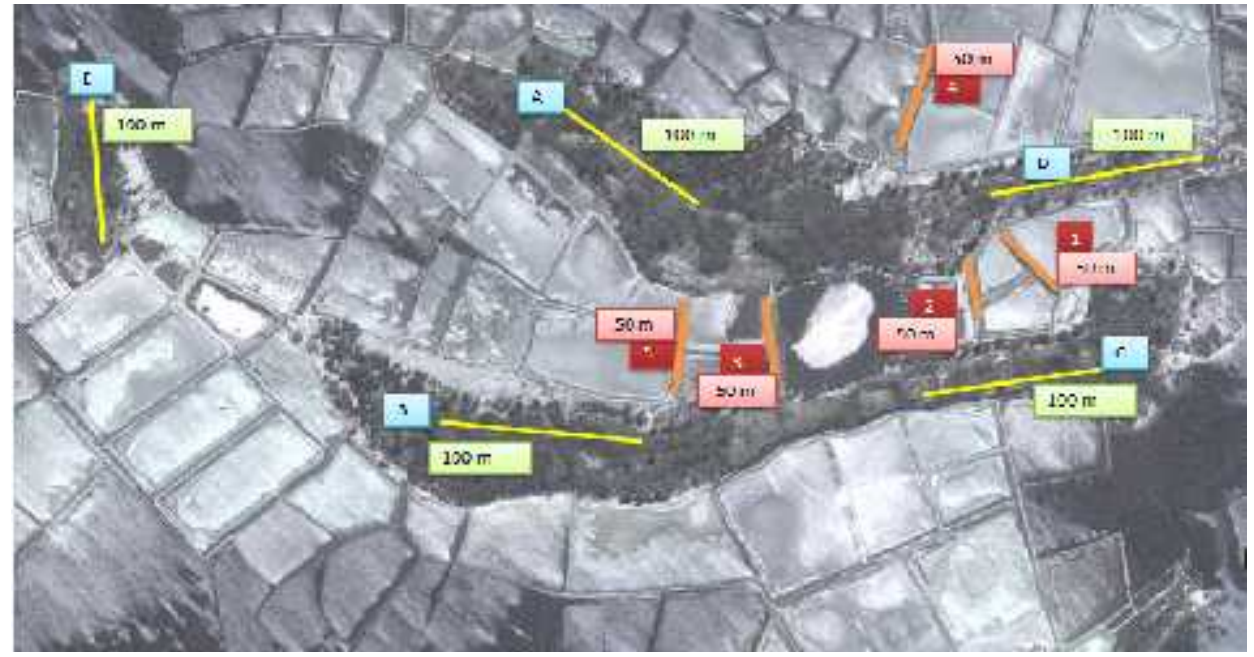

Gambar 3: Pembagian stasiun dan transek sampling mangrove asosiasi di Desa Balandatu

Pengambilan data pada daerah non tambak dilakukan menggunakan transek sepanjang $100 \mathrm{~m}$ dengan 5 plot berukuran $10 \times 10 \mathrm{~m}$ pada beberapa titik di daerah yang masih ditumbuhi oleh mangrove asosiasi. Kemudian dalam plot $10 \times 10 \mathrm{~m}$ dibentuk plot "nested kuadrat" untuk memudahkan perhitungan sampel mangrove asosiasi dengan beberapa kategori yaitu, herba, anakan, semak, perdu dan pohon. Sebagian besar kawasan yang dulunya menjadi habitat bagi mangrove asosiasi, kini telah berubah menjadi area tambak yang luas.

Pengambilan sampel juga dilakukan di pematang tambak yang ditumbuhi mangrove asosiasi menggunakan transek sabuk ukuran $50 \times 1 \mathrm{~m}$. Dalam transek tersebut dibuat plot ukuran $1 \times 1 \mathrm{~m}$ sebanyak 5 plot dengan jarak antar plot $10 \mathrm{~m}$. Dalam setiap plot dibuat 25 kotak kecil untuk memudahkan perhitungan kerapatan tegakan rumput di daerah tambak.

Data jumlah tegakan dan jenis mangrove asosiasi yang ada di dalam plot dicatat.Sampel daun, bunga, dan buah diambil sebagai bahan identifikasi.Penutupan tajuk dan basal juga diukur untuk menentukan persentase penutupannya.Untuk keperluan identifikasi dilakukan pembuatan herbarium terhadap sampel yang dikoleksi.Dokumentasi dilakukan terhadap koleksi sampel, habitus dan transek (plot).

\section{Analisis Data}

Data spesies mangrove asosiasi yang telah dikumpulkan kemudian dianalisis secara deskriptif dengan menggambarkan ciri spesies dari tumbuhan mangrove asosiasi serta taksonominya dengan berpedoman pada buku Panduan Pengenalan Mangrove di Indonesia (Noor, et. al., 2006).Untuk struktur vegetasi dilakukan perhitungan komponen struktur berupa kerapatan spesies mangrove asosiasi, kerapatan relatif, penutupan, penutupan relatif, frekuensi, frekuensi relatif, dan indeks nilai penting (INP).Untuk melihat dominansi spesies dalam satu transek maka dihitung dengan Standard Dominance Rasio (SDR). 


\begin{tabular}{|c|c|c|c|c|}
\hline 6 & Eupatorium odoratum & Asteraceae & - & + \\
\hline 7 & Caesalpina bonduc & Caesalpinaceae & - & + \\
\hline 8 & Tamarindus indica & Caesalpinaceae & - & + \\
\hline 9 & Salicornia sp. & Chenopodiaceae & - & + \\
\hline 10 & Lumnitzera littorea & Combretaceae & - & + \\
\hline 11 & Ipomoea batatas & Convolvulaceae & + & - \\
\hline 12 & Fimbristylis ferruginea & Cyperaceae & + & - \\
\hline 13 & Fimbristylis cymosa & Cyperaceae & + & + \\
\hline 14 & Cyperus sp. & Cyperaceae & + & - \\
\hline 15 & Phyllanthus niruri & Euphorbiaceae & + & - \\
\hline 16 & Phyllanthus amarus & Euphorbiaceae & - & + \\
\hline 17 & Breynia retusa & Euphorbiaceae & - & + \\
\hline 18 & Plectranthus sp. & Lamiaceae & - & + \\
\hline 19 & Leucaena leucocephala & Mimosaceae & - & + \\
\hline 20 & Musasp. & Musaceae & - & + \\
\hline 21 & Pandanus sp & Pandanaceae & - & + \\
\hline 22 & Passiflora foetida & Passifloraceae & - & + \\
\hline 23 & Bacopa monnieri & Plantaginaceae & + & - \\
\hline 24 & Heteropogon contortus & Poaceae & + & - \\
\hline 25 & Cenchrus echinatus & Poaceae & + & - \\
\hline 26 & Lepturus repens & Poaceae & + & - \\
\hline 27 & Imperata cylindrica & Poaceae & - & + \\
\hline 28 & Guettarda speciosa & Rubiaceae & - & + \\
\hline 29 & Aegle marmelos & Rutaceae & - & + \\
\hline 30 & Sterculia foetida & Sterculiaceae & - & + \\
\hline 31 & Heritiera littoralis & Sterculiaceae & - & + \\
\hline 32 & Guazuma ulmifolia & Sterculiaceae & - & + \\
\hline 33 & Stachytarpheta jamaicensis & Verbenaceae & - & + \\
\hline 34 & Lantara camara & Verbenaceae & - & + \\
\hline 35 & Spesies A (pohon) & & - & + \\
\hline 36 & Spesies B (semak) & & - & + \\
\hline \multicolumn{3}{|c|}{ Jumlah } & 11 & 26 \\
\hline
\end{tabular}

\section{Daerah Tambak}

Di daerah tambak diperolehhasil Standard Dominance Ratio (SDR) yang bervariasidi setiap stasiun. Nilai SDR berkisar 71,33\% hingga 100\%. Dari 9 spesies rumput SDR tertinggi ada pada spesies Fimbristylis cymosa dengan nilai SDR $100 \%$ di stasiun 1, kedua Heteropogon contortus pada stasiun 3 dengan SDR 93.08\% dan urutan ketiga Cenchrus echinatus dengan nilai SDR 71,33\% pada stasiun 4, yang menunjukkan dominansi, penguasaan ruang dan derajat penyebaran spesies-spesies rumput yang tinggi ditemukan pada daerah tambak. Dengan perbandingan rasio setiap spesies dalam satu transek(Tabel 2).

Tabel 2 Mangrove asosiasi di daerah tambak Desa Balandatu

\begin{tabular}{|c|c|c|c|c|c|c|c|}
\hline \multicolumn{7}{|l|}{ Stasiun 1 } \\
\hline NAMA SPESIES & KM & KR $(\%)$ & FM & FR $(\%)$ & PM & PR $(\%)$ & SDR \\
\hline Fimbristylis cymosa & 3,2 & 100 & 0,4 & 100 & 3,2 & 100 & 100 \\
\hline Jumlah & & 100 & & 100 & & 100 & \\
\hline Stasiun 2 & 6,4 & 6,04915 & 0,2 & 20 & 2,4 & 11,7647 & 12,61 \\
\hline Fimbristylis cymosa & 98,6 & 93,1947 & 0,6 & 60 & 12,4 & 60,7843 & 71,33 \\
\hline Cenchrus echinatus &
\end{tabular}


BIOMA : JURNAL BIOLOGI MAKASSAR. 2(1): 21-35, 2017

\begin{tabular}{|c|c|c|c|c|c|c|c|}
\hline Ipomoea batatas & 0,8 & 0,75614 & 0,2 & 20 & 5,6 & 27,451 & 16,07 \\
\hline Jumlah & & 100 & & 100 & & 100 & \\
\hline \multicolumn{8}{|l|}{ Stasiun 3} \\
\hline Heteropogon contortus & 274,8 & 99,4211 & 0,8 & 80 & 46,8 & 99,8294 & 93,08 \\
\hline Cenchrus echinatus & 1,6 & 0,57887 & 0,2 & 20 & 0,08 & 0,17065 & 6,92 \\
\hline Jumlah & & 100 & & 100 & & 100 & \\
\hline \multicolumn{8}{|l|}{ Stasiun 4} \\
\hline Cenchrus echinatus & 74,4 & 93 & 1 & 50 & 40,4 & 80,1587 & 74,39 \\
\hline Bacopa monnieri & 0,8 & 1 & 0,2 & 10 & 0,4 & 0,79365 & 3,93 \\
\hline Blumea balsamifera & 3,2 & 4 & 0,4 & 20 & 2 & 3,96825 & 9,32 \\
\hline Phyllanthus niruri & 0,8 & 1 & 0,2 & 10 & 0,4 & 0,79365 & 3,93 \\
\hline Lepturus repens & 0,8 & 1 & 0,2 & 10 & 7,2 & 14,2857 & 8,43 \\
\hline Jumlah & & 100 & & 100 & & 100 & \\
\hline \multicolumn{8}{|l|}{ Stasiun 5} \\
\hline Lepturus repens & 66 & 90,1639 & 0,4 & 50 & 14,4 & 85,7143 & 75,29 \\
\hline Cyperus sp. & 0,8 & 1,0929 & 0,2 & 25 & 0,8 & 4,7619 & 10,29 \\
\hline Bacopa monnieri & 6,4 & 8,74317 & 0,2 & 25 & 1,6 & 9,52381 & 14,42 \\
\hline Jumlah & & 100 & & 100 & & 100 & \\
\hline
\end{tabular}

Fimbristylis cymosa merupakan satu-satunya spesies mangrove asosiasi yang ditemukan di stasiun 1.Hal ini disebabkan karena daerah pematang di stasiun 1 ditimbun secara berkala oleh masyarakat setempat.Heteropogon contortus memiliki habitat dengan kondisi kering dan terbuka yang langsung disinari oleh matahari.Heteropogon contortusmemiliki tingkat adaptasi yang baik di daerah kering dan dapat berkembang biak dengan menggunakan biji dan tunasnya (pertumbuhan vegetatif) sehingga memungkinkan mendominasi suatu daerah akan tetapi tidak dapat berkembang dengan baik di daerah yang lembab dan tergenang air.

Di sekitar stasiun 4 terdapat spesies Sesuvium portulacastrumyang tumbuh dengan membentuk rumpun di tepian pematang tambak.Sesuvium portulacastrumseringkali ditemukan disepanjang tepi daratan mangrove, pada areal yang secara tidak teratur digenangi oleh pasang surut. Memiliki biji berwarna hitam, halus dan panjangnya $1,5 \mathrm{~mm}$ sehingga penyebaran bijinya dibantu oleh angin hal ini yang memungkinkannya dapat tumbuh menyebar di daerah tambak. Tumbuhan halofitaini ditemukan di daerah pesisir di sepanjang pesisir Jawa, Madura, Sulawesi dan Sumatera. Penelitian Rabhi (2008) menyatakan bahwa dari tiga jenis tumbuhan halofita (Sesuvium portulacastrum,Suaeda fruticosa dan Arthorecnemum indicum), ternyata Sesuvium memliki daya serap ion $\mathrm{Na}$ lebih besar (26\%) dibandingkan dua spesies lainnya (8\%).

\section{Daerah Non Tambak}

Daerah non tambak umumnya didominasi oleh substrat berpasir dengan kondisi daerah yang kering dan telah dikonversi oleh masyarakat sebagai kebun. Daerah mangrove asosiasi di daerah non tambak juga terpapar angin yang mengandung garam sehingga menyebabkan mangrove asosiasi memiliki kadar salinitas yang tinggi. 


\section{Stasiun 1}

Stasiun 1 memiliki substrat berpasir yang didominasi oleh vegetasi semak dan perdu.Permukaan tanah ditutupi oleh lapisan serasah yang tebal sehingga jenis herba jarang ditemukan tumbuh di bawah naungan semak atau pohon.Di sekitar stasiun 1 terdapat pohon seperti pohon Tammate Lannea coromandelica.Pada stasiun 1 diperoleh 9 spesies mangrove asosiasi (Tabel 3).

Tabel 3. Mangrove asosiasi di daerah non tambak Desa Balandatu (Stasiun 1)

\begin{tabular}{|c|c|c|c|c|c|c|c|}
\hline \multicolumn{8}{|l|}{ Anakan (Individu/m2) } \\
\hline NAMA SPESIES & $\mathbf{K M}$ & KR (\%) & FM & FR $(\%)$ & PM & PR $(\%)$ & SDR \\
\hline Laucaena leucocephala & 1,8 & 28,125 & 0,8 & 50 & 1,3629 & 26,9462 & 35,02 \\
\hline Lannea coromandelica & 0,2 & 3,125 & 0,2 & 12,5 & 0,01608 & 0,31786 & 5,31 \\
\hline Breynia retusa & 3,8 & 59,375 & 0,4 & 25 & 3,58337 & 70,8474 & 51,74 \\
\hline Heritiera littoralis & 0,6 & 9,375 & 0,2 & 12,5 & 0,09552 & 1,88852 & 7,92 \\
\hline Jumlah & & 100 & & 100 & & 100 & \\
\hline \multicolumn{8}{|l|}{ Semak (Individu/Hektar) } \\
\hline Eupatorium odoratum & 3.500 & 70 & 0,4 & 67 & $8.900,64$ & 63,6331 & 66,88 \\
\hline Lantana camara & 1.500 & 30 & 0,2 & 33 & $5.086,8$ & 36,3669 & 33,12 \\
\hline Jumlah & & 100 & & 100 & & 100 & \\
\hline \multicolumn{8}{|l|}{ Perdu (Individu/Hektar) } \\
\hline Pandanus sp. & 1.120 & 37,8378 & 0,8 & 40 & $27.521,5$ & 99,7887 & 59,21 \\
\hline Laucaena leucocephala & 720 & 24,3243 & 0,8 & 40 & 4,52102 & 0,01639 & 21,45 \\
\hline Guazuma ulmifolia & 960 & 32,4324 & 0,2 & 10 & 52,8306 & 0,19156 & 14,21 \\
\hline Morinda citrifolia & 160 & 5,40541 & 0,2 & 10 & 0,91975 & 0,00333 & 5,14 \\
\hline Jumlah & & 100 & & 100 & & 100 & \\
\hline
\end{tabular}

KirinyuEupatorium odorata mampu mendominasi di stasiun 1 dengan nilai SDR 66,88\%. Kemampuannya mendominasi area dengan cepat disebabkan oleh produksi bijinya yang sangat banyak.Setiap tumbuhan dewasa mampu memproduksi sekitar 80.000 biji setiap musim.Memiliki batang muda agak lunak dan berwarna hijau, kemudian berangsur-angsur menjadi cokelat dan keras (berkayu) apabila sudah tua.Letak cabang biasanya berhadap-hadapan dan jumlahnya sangat banyak.Cabangnya yang rapat menyebabkan cahaya matahari yang masuk ke bagian bawah berkurang. Sehingga menghambat pertumbuhan spesies lain, termasuk rumput yang tumbuh di bawahnya. (Prawiradiputra,1985).

\section{Stasiun 2}

Habitat mangrove asosiasi di sekitar stasiun 2 sudah dikonversi menjadi kebun oleh masyarakat.Hal ini dapat dilihat dari ditemukannya tanaman-tanaman budidaya sepertiPisangMusa sp. dan KelapaCocos nucifera serta ditemukannya guludan yang kemungkinan digunakan untuk bercocok tanam pada saat musim hujan.

Tabel 4. Mangrove asosiasi di daerah non tambak Desa Balandatu (Stasiun 2)

\begin{tabular}{|c|c|c|c|c|c|c|c|}
\hline \multicolumn{8}{|l|}{ Herba (Individu/m²) } \\
\hline NAMA SPESIES & KM & KR (\%) & FM & FR $(\%)$ & $\mathbf{P M}$ & PR (\%) & SDR \\
\hline Plectranthus sp. & 0,4 & 100 & 0,2 & 100 & 2 & 100 & 100 \\
\hline Jumlah & & 100 & & 100 & & 100 & \\
\hline \multicolumn{8}{|l|}{ Anakan (Individu/m²) } \\
\hline Breynia retusa & 0,2 & 33,3333 & 0,2 & 33,3333 & 0,07065 & 66,4109 & 44,36 \\
\hline Leucaena leucocephala & 0,4 & 66,66667 & 0,4 & 66,6667 & 0,03573 & 33,5891 & 55,64 \\
\hline Jumlah & & 100 & & 100 & & 100 & \\
\hline
\end{tabular}


BIOMA : JURNAL BIOLOGI MAKASSAR. 2(1): 21-35, 2017

\begin{tabular}{|c|c|c|c|c|c|c|c|}
\hline \multicolumn{8}{|l|}{ Semak (Individu/Hektar) } \\
\hline Phyllanthus amarus & 80.000 & 93,0233 & 0,4 & 40 & 202.687 & 93,7783 & 75,6 \\
\hline Stachytarpheta jamaicensis & 2.500 & 2,906977 & 0,2 & 20 & 232,713 & 0,10767 & 7,67 \\
\hline Eupatorium odoratum & 10.00 & 1,16279 & 0,2 & 20 & $4.171,33$ & 1,92997 & 7,69 \\
\hline Salicornia sp. & 2.500 & 2,90698 & 0,2 & 20 & $9.043,2$ & 4,18406 & 9,03 \\
\hline Jumlah & & 100 & & 100 & & 100 & \\
\hline \multicolumn{8}{|l|}{ Perdu (Individu/Hektar) } \\
\hline Musa sp. & 240 & 30 & 0,2 & 20 & $2.628,86$ & 57,5191 & 35,84 \\
\hline Cocos nucifera & 240 & 30 & 0,6 & 60 & $1.938,01$ & 42,4033 & 44,13 \\
\hline Leucaena leucocephala & 320 & 40 & 0,2 & 20 & 3,54729 & 0,07761 & 20,02 \\
\hline Jumlah & & 100 & & 100 & & 100 & \\
\hline \multicolumn{8}{|l|}{ Pohon (Individu/Hektar) } \\
\hline Cerbera manghas & 20 & 12,5 & 0,2 & 20 & 0,0078 & 5,52113 & 12,67 \\
\hline Spesies A (pohon) & 20 & 12,5 & 0,2 & 20 & 0,00027 & 0,19042 & 10,89 \\
\hline Breynia retusa & 60 & 37,5 & 0,2 & 20 & 0,0023 & 1,62704 & 19,71 \\
\hline Lannea coromandelica & 60 & 37,5 & 0,4 & 40 & 0,13095 & 92,6614 & 56,72 \\
\hline Jumlah & & 100 & & 100 & & 100 & \\
\hline
\end{tabular}

Pada stasiun 2 tercatat 13 spesies mangrove asosiasi yang dapat ditemukan pada saat pengamatan (Tabel4). Jenis herba dan anakan tidak banyak ditemukan distasiun 2 disebabkan tebalnya serasah daun yang menutupi permukaan tanah.Lapisan serasah tersebut berasal dari guguran daun mangrove asosiasi yang mengandung garam akibat akumulasi garam pada tanah.Selain itu, lapisan tajuk semak dan perdu menghalangi penetrasi cahaya matahari sehingga herba dan anakan tidak mampu tumbuh di bawah semak dan perdu.Nilai SDR tertinggi menunjukkan Phyllanthus amarusdengan SDR $75,6 \%$ mendominasi stasiun 2 baik dari penyebaran ataupun penguasaan ruangnya.

Hasil yang ditemukan di stasiun 2, spesies yang tergolong kedalam familia Euphorbiaceaetersebut mampu mendominasi habitatnya. Hal ini disebabkan tumbuhan tersebut memiliki buah yang terletak di ketiak daunsehingga pada saat jatuh akan tumbuh di sekitar indukannya, memungkinkan anakan untuk tumbuh mengelompok.

Di stasiun 2, juga terdapat Salicornia sp. yang tumbuh dengan membentuk rumpun, tidak tersebar secara merata di daerah mangrove asosiasi dan hanya ditemukan distasiun 2.Salicornia sp. tumbuh di daerah yang langsung terkena sinar matahari dengan mendominasi area tertentu. Tidak ditemukan adanya jenis tumbuhan lain yang tumbuh di area yang didominasi oleh Salicornia sp. tersebut. Menurut Campbell et.al (2002) spesies yang dominan seperti Salicornia sp. memiliki kemampuan mengontrol pertumbuhan dari populasi spesies lain.

\section{Stasiun 3}

Daerah mangrove asosiasi di stasiun 3 didominasi oleh semak berupa yang menbentuk rumpun di sepanjang stasiun 3 dengan substrat yang berpasir.Terdapat pohon Tammate Lannea coromandelica yang berjajar membentuk pagar yang dimanfaatkan oleh masyarakat sebagai pembatas wilayahnya karena pohon Tammate mudah tumbuh di kawasan mangrove asosiasi.Terdapat 8 spesies mangrove asosiasi pada stasiun 3.Spesies yang memiliki nilai SDR tertinggi di stasiun 3 yaitu AlangAlangImperata cylindrica dengan nilai $100 \%$.Hal ini menunjukkan dominansi AlangAlang di stasiun 3. 
Tabel 5. Mangrove asosiasi di daerah non tambak Desa Balandatu (Stasiun 3)

\begin{tabular}{|c|c|c|c|c|c|c|c|}
\hline \multicolumn{8}{|l|}{ Rumput (Individu/m²) } \\
\hline NAMA SPESIES & $\mathbf{K M}$ & KR $(\%)$ & FM & FR $(\%)$ & $\mathbf{P M}$ & PR (\%) & SDR \\
\hline Imperata cylindrica & 7,4 & 100 & 0,6 & 100 & 26,9 & 100 & 100 \\
\hline Jumlah & & 100 & & 100 & & 100 & \\
\hline \multicolumn{8}{|l|}{ Anakan (Individu/m²) } \\
\hline Lannea coromandelica & 0,4 & 28,5714 & 0,2 & 25 & 0,56677 & 13,4378 & 22,34 \\
\hline Sterculia foetida & 0,6 & 42,85714 & 0,2 & 25 & 3,54231 & 83,9863 & 50,61 \\
\hline Spesies A (anakan) & 0,2 & 14,2857 & 0,2 & 25 & 0,02267 & 0,53751 & 13,27 \\
\hline Leucaena leucocephala & 0,2 & 14,2857 & 0,2 & 25 & 0,08597 & 2,03838 & 13,77 \\
\hline Jumlah & & 100 & & 100 & & 100 & \\
\hline \multicolumn{8}{|l|}{ Semak (Individu/Hektar) } \\
\hline Passiflora foetida & 500 & 20 & 0,2 & 50 & 3,925 & 3,56633 & 24,52 \\
\hline Eupatorium odoratum & 2.000 & 80 & 0,2 & 50 & 106,132 & 96,4337 & 75,48 \\
\hline Jumlah & & 100 & & 100 & & 100 & \\
\hline \multicolumn{8}{|l|}{ Perdu (Individu/Hektar) } \\
\hline Pandanus sp. & 80 & 33,3333 & 0,33333 & 33,3333 & 392,5 & 96,432 & 54,37 \\
\hline Leucaena leucocephala & 160 & 66,6667 & 0,66667 & 66,6667 & 14,5225 & 3,56799 & 45,63 \\
\hline Jumlah & & 100 & & 100 & & 100 & \\
\hline \multicolumn{8}{|l|}{ Pohon (Individu/Hektar) } \\
\hline Lannea coromandelica & 340 & 89,4737 & 0,6 & 75 & 51,1622 & 95,6849 & 86,72 \\
\hline Sterculia foetida & 40 & 10,5263 & 0,2 & 25 & 2,30729 & 4,31515 & 13,28 \\
\hline Jumlah & & 100 & & 100 & & 100 & \\
\hline
\end{tabular}

Pada Tabel 5 terlihat Imperata cylindricamendominasi di stasiun 5 dengan SDR $100 \%$.Hal ini disebabkan, tumbuhan tersebut memiliki bunga yang berbentuk malai dengan bulir bunga yang tersusun rapat, berbentuk ellips meruncing yang sangat ringan dan mempunyai rambut-rambut halus sehingga mudah terbawa angin. Selain dapat berkembang biak dengan biji juga dapat memperbanyak diri dengan rimpangnya.Hal ini yang menyebabkan derajat penyebaran Alang-Alang di stasiun 3 lebih tinggi dibandingkan dengan spesies lainnya (Damaru, 2011).

\section{Stasiun 4}

Stasiun 4 memiliki substrat berpasir yang ditutupi dengan serasah daun tebal dan didominasi semak dan pohon yang masing-masing membentuk rumpun.Terdapat 11 spesies mangrove asosiasi yang ditemukan di stasiun 4.Hanya terdapat 1 jenis rumput yang ditemukan stasiun 4 karena substrat ditutupi oleh serasah daun sehingga tidak memungkinkan untuk berbagai jenis rumput tumbuh di stasiun 4 .

Pada stasiun 4 rumput dan anakan pohon juga jarang ditemukan sesuai pada Tabel 6.Pohon Tammate Lannea coromandelica memiliki nilai SDR tertinggi yaitu 63,46\%. Tabel 6 menunjukkan Lantana camaramendominasi stasiun 4.Merupakan tanaman semak yang dapat hidup di daerahpertanian, pesisir, hutan alam, dan lahan basah.Lantana camaramerupakan tanaman invasif yang termasuk dalam familia Verbenaceae (Susanti et. al., 2013).

Pada stasiun 4 juga terdapat Heritiera littoralis yang ditemukan hanya di plot 5 dan juga membentuk rumpun tersendiri. Heritiera littoralis sangat umum ditemukan di tepi daratan mangrove, memiliki akar papan yang sangat jelas dengan kulit kayunya yang gelap. Memiliki buah yang berwarna hijau hingga coklat dengan 1 biji yang masak pada tandan yang bergantung. Ukurannya dapat mencapai panjang 6-9 $\mathrm{cm}$ dan lebar 5-6 cm (Noor, et. al., 2006). 
Tabel 6. Mangrove asosiasi di daerah non tambak Desa Balandatu (Stasiun 4)

\begin{tabular}{|c|c|c|c|c|c|c|c|}
\hline \multicolumn{8}{|l|}{ Rumput (Individu/m²) } \\
\hline NAMA SPESIES & KM & KR $(\%)$ & FM & $\operatorname{FR}(\%)$ & PM & PR $(\%)$ & SDR \\
\hline Fimbristylis cymosa & 0,2 & 100 & 0,2 & 100 & 0,2 & 100 & 100 \\
\hline Jumlah & & 100 & & 100 & & 100 & \\
\hline \multicolumn{8}{|l|}{ Anakan (Individu/m²) } \\
\hline Lannea coromandelica & 0,2 & 33,3333 & 0,2 & 50 & 0,20763 & 14,5224 & 32,62 \\
\hline Leucaena leucocephala & 0,4 & 66,66667 & 0,2 & 50 & 1,2221 & 85,4776 & 67,38 \\
\hline Jumlah & & 100 & & 100 & & 100 & \\
\hline \multicolumn{8}{|l|}{ Semak (Individu/Hektar) } \\
\hline Passiflora foetida & 500 & 11,1111 & 0,6 & 42,8571 & $1.747,45$ & 7,78311 & 20,58 \\
\hline Spesies B (Semak) & 1.000 & 22,22222 & 0,4 & 28,5714 & $2.986,93$ & 13,3037 & 21,37 \\
\hline Eupatorium odoratum & 1.000 & 22,2222 & 0,2 & 14,2857 & $1.134,33$ & 5,05226 & 13,85 \\
\hline Lantana camara & 2.000 & 44,4444 & 0,2 & 14,2857 & $16.583,1$ & 73,8609 & 44,19 \\
\hline Jumlah & & 100 & & 100 & & 100 & \\
\hline \multicolumn{8}{|l|}{ Perdu (Individu/Hektar) } \\
\hline Musa sp. & 560 & 43,75 & 0,4 & 33,3333 & $4.415,4$ & 98,001 & 58,36 \\
\hline Caesalpina bonduc & 80 & 6,25 & 0,2 & 16,6667 & 75,988 & 1,68657 & 8,201 \\
\hline Leucaena leucocephala & 640 & 50 & 0,6 & 50 & 14,0758 & 0,31242 & 33,44 \\
\hline Jumlah & & 100 & & 100 & & 100 & \\
\hline \multicolumn{8}{|l|}{ Pohon (Individu/Hektar) } \\
\hline Guettarda speciosa & 40 & 33,3333 & 0,2 & 20 & 0,09952 & 1,07105 & 18,13 \\
\hline Lannea coromandelica & 60 & 50 & 0,6 & 60 & 7,47022 & 80,3938 & 63,46 \\
\hline Heritiera littoralis & 20 & 16,6667 & 0,2 & 20 & 1,72229 & 18,5351 & 18,401 \\
\hline Jumlah & & 100 & & 100 & & 100 & \\
\hline
\end{tabular}

\section{Stasiun 5}

Tercatat 13 spesies mangrove asosiasi ditemukan selama pengamatan di stasiun 5.Pohon AsamTamarindus indica dan Kepuh Sterculia foetida ditemukan pada stasiun 5.Pada stasiun 5 juga tidak ditemukan adanya rumput, disebabkan tutupan serasah daun yang tebal di daerah tersebut.Standard Dominance Ratio (SDR) tertinggi pada stasiun 5 KirinyuEupatorium odoratadengan nilai $71,01 \%$. Hal ini menunjukkan dominansi dari Kirinyu Eupatorium odoratapada stasiun 5 baik dari penguasaan ruang dan penyebarannya (Tabel 7).

Tabel 7. Mangrove asosiasi di daerah non tambak Desa Balandatu (Stasiun 5)

\begin{tabular}{|c|c|c|c|c|c|c|c|}
\hline \multicolumn{8}{|l|}{ Anakan (Individu/m²) } \\
\hline NAMA SPESIES & KM & KR $(\%)$ & FM & FR $(\%)$ & PM & PR (\%) & SDR \\
\hline Morinda citrifolia & 0,2 & 16,6667 & 0,2 & 33,3333 & 0,03468 & 5,64197 & 18,55 \\
\hline Leucaena leucocephala & 0,8 & 66,66667 & 0,2 & 33,3333 & 0,5549 & 90,2715 & 63,42 \\
\hline Spesies F (anakan) & 0,2 & 16,6667 & 0,2 & 33,3333 & 0,02512 & 4,08653 & 18,03 \\
\hline Jumlah & & 100 & & 100 & & 100 & \\
\hline \multicolumn{8}{|l|}{ Semak (Individu/Hektar) } \\
\hline Eupatorium odorata & 4.500 & 69,2308 & 0,4 & 66,6667 & $1.662,04$ & 77,1466 & 71,01 \\
\hline Spesies I (Semak) & 2.000 & 30,76923 & 0,2 & 33,3333 & 492,352 & 22,8534 & 28,99 \\
\hline Jumlah & & 100 & & 100 & & 100 & \\
\hline \multicolumn{8}{|l|}{ Perdu (Individu/Hektar) } \\
\hline Musa sp. & 80 & 10 & 0,8 & 40 & 141,3 & 7,12686 & 19,04 \\
\hline Cocos nucifera & 160 & 20 & 0,4 & 20 & $1.664,2$ & 83,9386 & 41,31 \\
\hline Pandanus sp. & 400 & 50 & 0,4 & 20 & 176,625 & 8,90858 & 26,302 \\
\hline Leucaena leucocephala & 160 & 20 & 0,4 & 20 & 0,51465 & 0,02596 & 13,34 \\
\hline Jumlah & & 100 & & 100 & & 100 & \\
\hline \multicolumn{8}{|l|}{ Pohon (Individu/Hektar) } \\
\hline Lannea coromandelica & 60 & 33,3333 & 0,6 & $42, .8571$ & 14,8186 & 67,9064 & 48,03 \\
\hline
\end{tabular}


BIOMA : JURNAL BIOLOGI MAKASSAR. 2(1): 21-35, 2017

\begin{tabular}{|c|c|c|c|c|c|c|c|}
\hline Spesies F (pohon) & 20 & 11,1111 & 0,2 & 14,2857 & 0,09172 & 0,42031 & 8,61 \\
\hline Aegle marmelos & 60 & 33,3333 & 0,2 & 14,2857 & 1,89188 & 8,66954 & 18,76 \\
\hline Tamarindus indica & 20 & 11,1111 & 0,2 & 14,2857 & 3,5828 & 16,4182 & 13,94 \\
\hline Sterculia foetida & 20 & 11,1111 & 0,2 & 14,2857 & 1,437 & 6,58552 & 10,66 \\
\hline Jumlah & & 100 & & 100 & & 100 & \\
\hline
\end{tabular}

\section{Indeks penyebaran Mangrove Asosiasi di Desa Balandatu}

Penyebaran mangrove asosiasi di Desa Balandatu Kepulauan Tanakeke umumnya membentuk pola penyebaran yang mengelompok berdasarkan analisis Indeks Morisita (Tabel 9).

Di daerah tambak hanya ditemukan herba seperti Heteropogon contortus(Gambar 3).Dikarenakan jika terdapat pohon ataupun semak di daerah tersebut maka ditebang oleh masyarakat karena digunakan sebagai jalan menuju tambak, nilai yang diperoleh dari stasiun 1 hingga stasiun 5 melebihi angka 1.Hal ini menunjukkan pola penyebaran herba di daerah tambak secara mengelompok.Spesies Heteropogon contortus, Cenchrus echinatus dan Sesuvium portulacastrum mendominasi didaerah tambak dan membentuk rumpun masing-masing.

Di daerah non tambak, herba terdapat di stasiun 2, 3, dan 4.Masing-masing memiliki nilai lebih dari 1.Dengan demikian, pola sebarannya juga mengelompok seperti halnya pada daerah tambak.Anakan pohon dari stasiun 1-5 pada daerah tambak juga memiliki nilai Indeks Morisita lebih dari 1.Begitupun dengan kategori semak, perdu dan pohon yang rata-rata di setiap stasiun memiliki nilai Indeks Morisita melebihi 1. Hal ini membuktikan bahwa dalam proses penyebarannya tumbuhan di daerah mangrove asosiasi cenderung memiliki pola mengelompok.

Spesies mangrove asosiasi cenderung mengelompok disebabkan adanya pengaruh faktor-faktor lingkungan seperti air, suhu, salinitas, tanah, $\mathrm{pH}$, cahaya dan substrat. Selain itu perbanyakan individu pada jenis herba seperti Heteropogon contortus yang memperbanyak diri secara vegetatif juga berpengaruh terhadap pola penyebarannnya sehingga tumbuh dengan membentuk rumpun.Menurut Cox dan Moore (1995) tiap-tiap lingkungan memiliki karakteristik tersendiri yang menyebabkannya dapat ditumbuhi oleh tumbuhan.

Tabel 8. Penyebaran Mangrove asosiasi di Desa Balandatu

\begin{tabular}{|c|c|c|c|c|c|c|c|c|c|c|c|}
\hline & & \multicolumn{5}{|c|}{ Stasiun Tambak } & \multicolumn{5}{c|}{ Stasiun Non Tambak } \\
\cline { 3 - 13 } No & Kategori & $\mathbf{1}$ & $\mathbf{2}$ & $\mathbf{3}$ & $\mathbf{4}$ & $\mathbf{5}$ & $\mathbf{1}$ & $\mathbf{2}$ & $\mathbf{3}$ & $\mathbf{4}$ & $\mathbf{5}$ \\
\hline 1 & Herba & 3 & 3.6 & 1.707 & 3.348 & 1.53 & 0 & 5 & 2.598 & 0 & 0 \\
\hline 2 & Anakan & & & & & & 2.611 & 1.67 & 3.571 & 5 & 2.33 \\
\hline 3 & Semak & & & & & & 4 & 2.358 & 5 & 2.083 & 1.795 \\
\hline 4 & Perdu & & & & & 0.879 & 2.444 & 0 & 2.042 & 1.111 \\
\hline 5 & Pohon & & & & & & 3.681 & 1.964 & 1.842 & 1.333 & 1.805 \\
\hline
\end{tabular}

Keterangan:

1. Jika Id $=1$, maka pola sebarannya acak

2. Jika Id $>1$, maka pola sebarannya mengelompok

3. Jika Id $<1$ maka pola sebarannya seragam 


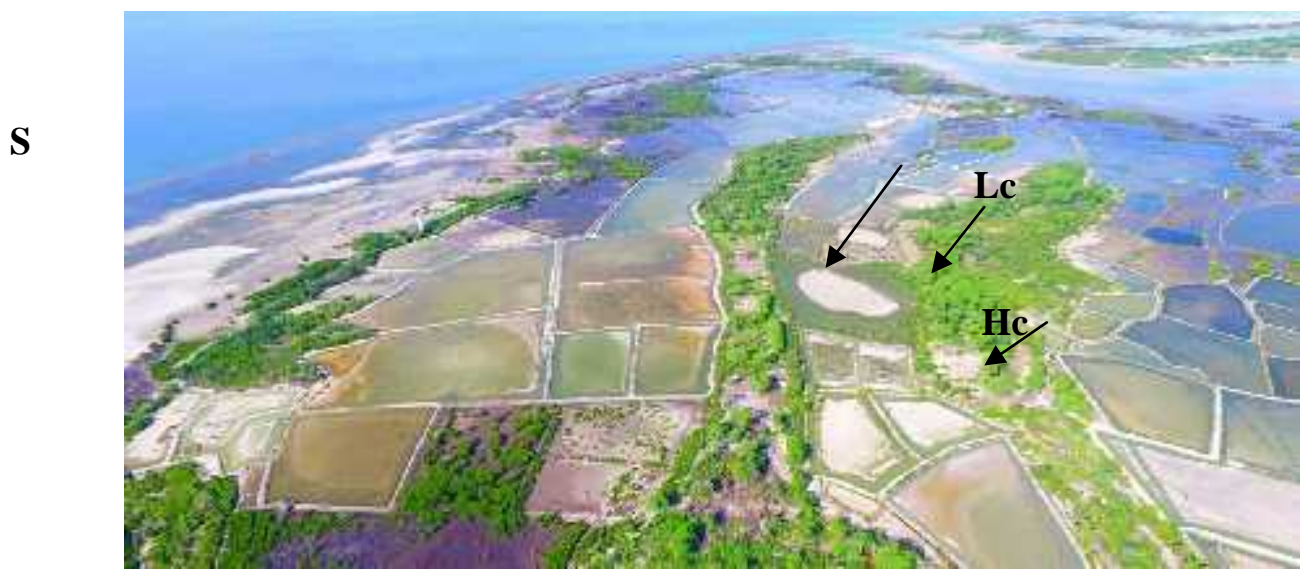

Gambar 4.Foto udara sebaran mangrove asosiasi di Desa Balandatu.S= Salicornia sp., Lc= Lannea coromandelica, Hc= Heteropogon contortus. (Foto: Muh. Teguh Nagir, 2016)

Pola penyebaran biji mangrove asosiasi juga berpengaruh terhadap pertumbuhan mangrove asosiasi secara mengelompok di daerah tersebut. Salah satunya dibantu oleh angin seperti Eupatorium odorata yang merupakan tumbuhan invasif dengan perkembangan sangat cepat dan membentuk komunitas yang rapat sehingga dapat menghalangi perkembangan tumbuhan lain. Hal ini menyebabkan Eupatorium odorata mampu mendominasi daerah tertentu di kawasan mangrove asosiasi dengan membentuk rumpun.

\section{Faktor Lingkungan Mangrove Asosiasi di Desa Balandatu}

Hasil pengambilan data menunjukkan, suhu di daerah mangrove asosiasi Desa Balandatu Kepulauan Tanakeke berkisar $30-33^{\circ} \mathrm{C}$ (Tabel 10).Perbedaan suhu di daerah tambak dan daerah non tambak disebabkan pada daerah tambak merupakan lahan terbuka dengan intensitas cahaya yang tinggi.Nilai suhu tertinggi diperoleh di daerah tambak stasiun 3 disebabkan waktu pengambilan data pada pukul 12:15 WITA.

Tabel 9.Perbedaan suhu di daerah tambak dan non tambak daerah mangrove asosiasi Desa Balandatu.

\begin{tabular}{|c|c|c|c|}
\hline No. & Daerah & Stasiun & Suhu $\left({ }^{\circ} \mathrm{C}\right)$ \\
\hline \multirow{5}{*}{1} & \multirow{5}{*}{ Tambak } & 1 & 32 \\
\hline & & 2 & 31 \\
\hline & & 3 & 33 \\
\hline & & 4 & 32 \\
\hline & & 5 & 31 \\
\hline \multirow{5}{*}{2} & \multirow{5}{*}{ Non Tambak } & 1 & 31 \\
\hline & & 2 & 30 \\
\hline & & 3 & 30 \\
\hline & & 4 & 31 \\
\hline & & 5 & 31 \\
\hline
\end{tabular}

Berdasarkan hasil penelitian Utina, et.al (2012) rentan toleransi spesies mangrove asosiasi terhadap suhu lingkungan berkisar $31-41^{0}$ C.Faktor lingkungan tersebut sangat mempengaruhi keberadaan suatu spesies di daerah mangrove asosiasi karena merupakan prasyarat tumbuhan tersebut untuk tumbuh dan berkembang.Seperti 
halnya yang dikemukakan oleh Katili (2008), agar dapat tumbuh dan berkembang secara baik, masing-masing spesies membutuhkan persyaratan tumbuh yang berbeda sehingga memungkinkan terjadinya efisiensi alokasi energi untuk pertumbuhannya.

\section{Kesimpulan}

Berdasarkan hasil penelitian yang Berdasarkan hasil penelitian yang telah dilakukan, dapat disimpulkan sebagaiberikut :

Di sekitar area tambak Desa Balandatu Kepulauan Tanakeke Kabupaten Takalar, ditemukan 36 spesies Mangrove asosiasi dari 22 familia.Jumlah spesies yang ditemukan di daerah non tambak (26 spesies, 19 familia), lebih tinggi dibandingkan daerah tambak (11 spesies, 7 familia).

Mangrove asosiasi di Desa Balandatu Kepulauan Tanakeke ditemukan di daerah tambak dan daerah non tambak.Di daerah tambak terdapat 5 stasiun yang di dominasi oleh rumput.Standard Dominance Rasio (SDR) tertinggi berada di stasiun 1 ditemukan pada Fimbristylis cymosa(100\%). Sedangkan di daerah non tambak dari 5 stasiun, SDR tertinggi terdapat di stasiun 3 pada kategori semak yaituEupatorium odoratum $(75,48 \%)$.Hasil perhitungan Indeks Morisita menunjukkan, di setiap kategori mangrove asosiasi baik di daerah tambak dan non tambak memiliki nilai $>1$ yang mengindikasikan pola penyebaran mangrove asosiasi di daerah tersebut cenderung mengelompok.

\section{Ucapan Terima Kasih}

Terima kasih kepada direktur yayasan Hutan Biru Indonesia Muhammad Yusran dan tim penelitinya: Rispah Hamzah, Muh.Ikram dan Sardi Andis atas bahan referensi dan bantuan yang diberikan saat pengambilan data di lapangan.Terima kasih juga kepada Muh.Teguh Nagir untuk foto udara lokasi penelitian.

\section{Daftar Pustaka}

Brown, B. M., 2012, Mangrove Management Challenges on Tanakeke Island, Mangrove Journal, Restoring Coastal Livelihoods, CIDA, OXFAM-GB, MAPIndonesia, South Sulawesi.

Campbell, N. A. dan Reece, J. B., 2002, Biology Sixth Edition, University Of California, California.

Cox, C. B. dan Moore, P. D., 1985, Biogeography An Ecological and Evolution Aprroach Fouth Edition, Blackwee Scientific Publication, London.

Damaru, 2011, Alang-Alang, Ekologi Tumbuhan, Universitas Sumatera Utara, Medan, 29 p.

Faizal, A., 2006, Pemetaan Luasan dan Kerapatan Hutan Mangrove di Pulau Tanakeke Kabupaten Takalar Dengan Transformasi NDVI, Jurnal Torani, Fakultas Ilmu Kelautan dan Perikanan, Universitas Hasanuddin, Makassar (16): 2.

Katili, A. S., 2008, Penurunan Jasa (Servis) Ekosistem Sebagai Pemicu MeningkatnyaPerubahan Iklim Global, Jurnal Pelangi Ilmu, Jurusan Biologi Fakultas MIPA, Universitas Negeri Gorontalo, Gorontalo (1): 1-11.

Noor, Y. S., Khazali, M dan Suryadiputra, I. N. N., 2006, Panduan Pengenalan Mangrove di Indonesia, Wetland International-Indonesia Programme, Bogor.

Odum, H., 1993,Ekologi Sistem Suatu Pengantar, Universitas Gadjah Mada, Yogyakarta. 
Prawiradiputra, B. R., 1985, Perubahan Komposisi Vegetasi Padang RumputAlam Akibat Pengendalian KirinyuEupatorium odorata $(L) R$. M King and H. Robinson di Jonggol, Jawa Barat, Thesis, Fakultas Pascasarjana Institut Pertanian Bogor.

Rabhi, M., Walid, Z., Siwar, F., Abderrazak S. dan Chedly A., 2012 Phytodesalination: a Solution For Salt-affected Soil in Arid and Semi-arid Regions, Journal of Arid Land Studies (22) : 229-302.

Susanti, T., Suraida dan Harlis F., 2013, Keanekaragaman Tumbuhan Infasif di Kawasan Taman Hutan Kenali Kota Jambi, Program Studi Biologi, Fakultas Tarbiyah IAIN Sulthan Thaha Saifuddin Jambi.

Utina, R., 2008, Pendidikan Lingkungan Hidup dan Konservasi Sumberdaya Alam Pesisir, Universitas Negeri Gorontalo, Gorontalo.

Wang. L., Meirong, Mo., Xiaofei, Li., Peng, L. and Wenqin W., 2010, Differentiation Between True Mangrove and Mangrove Associates Based On Leaf Traits and Salt Contents, Journal Of Plant Ecology, Xiamen University, Pages 1-10. 